out, the pisolites decrease in size, manganite becomes important and the silica and phosphorus contents increase. Still farther out, under conditions of oxygen deficiency, carbonates appear (rhodocrosite and manganocalcite) with glauconite, and there is marked enrichment in phosphates, sulphides and opal. Eventually the carbonates feather out and finally the ore-horizon is represented only by rare nodules of phosphorite.

(b) Deposits associated with calcareous sediments occur in the mountain ranges of west and central Siberia. They are mostly of late Pre-Cambrian age, but important occurrences are also found in the Cambrian of the Alatau. In the western Urals there are similar deposits of Permian age. The chief ore mineral in this type is manganocalcite.

(c) Deposits associated with clastic sedimente are represented at Labinskoye in the Tertiary of the North Caucasus. Chemical sediments are absent and the ores (psilomelane, pyrolusite or manganese carbonates) occur as cementing material.

In regionally metamorphosed deposits, formed originally by sedimentation, anhydrous minerals are characteristic, for example, braunite and hausmannite, associated with magnetite and hæmatite and quartz. The waters liberated during metamorphism have given rise to veinlets which are mineralogically closely related to the enclosing rocks. Specific cases of this kind in Lower Carboniferous chemical sediments (siliceous and ferruginous) of Kazakhstan are described by Betekhtin and Suslov in the publication cited (pp. 86-99 and 100-108 respectively). Under conditions of more intense metamorphism, manganese silicates develop (rhodonite, spessartite, tephroite, piedmontite, etc.), and carbonate ores poor in silica form manganous marble. Here again, especially along belts of tectonic disturbance, migration and redistribution of manganese is indicated by the occurrence of veins and lenses of concentrated ore. These veins, though otherwise resembling hydrothermal deposits, are free from elements such as gold, silver, lead and zinc; their origin is purely metamorphic. Vein and contact metasomatic deposits genetically connected with the hydrothermal activity of associated acid plutonic rocks are of far greater abundance and importance. The ores vary widely in composition and structure and often occur with a typical assemblage of sulphide minerals. In many of these deposits, however, there is evidence that the manganese compounds were not magmatic derivatives, but were taken from the manganiferous country rocks through which the hydrothermal solutions circulated.

All the above types of manganese deposits become secondarily enriched by weathering processes in the zone of oxidation, the end product being a pyrolusitepsilomelane complex. Betekhtin directs attention to the widespread development in the early stages of weathering of a manganic 'acid', $\mathrm{H}_{2} \mathrm{MnO}_{3}$, which occurs as dispersed colloidal particles (brown) or as colloform masses (black). Previously mistaken for manganite, this mineraloid is now distinguished as 'vernadite' after the geochemist Vernadsky, who originally predicted its discovery as a natural product. It is suggested that the various members of the psilomelane group may be salts of this acid. Concentration by chemical weathering is further intensified by the tendency of manganese hydroxides to migrate in colloidal solution and, activated by adsorbed alkali cations, to replace quartz and silicate minerals metasomatically.

ARThur Holmes.

\section{CHESHUNT EXPERIMENTAL STATION}

$T$ HE Experimental and Research Station at Cheshunt, Herts, has given a valuable lead to the changing demands of war-time cropping of the glasshouse industry. Discussion of problems relating to tomato and lettuce culture occupies all the annual report for 1943* and provides an index to the concentration of the industry upon food crops.

One of the most interesting items in the report by the director, Dr. W. F. Bewley, is of trials of two Russian varieties of outdoor tomatoes. Stambovoi Alpatyev has a neat dwarf habit, bears fruit of good shape, scarlet and sweet; it seems well worth further trial. Bizon proved to be coarser, and gave badly shaped fruit, though neither variety was resistant to frost exceeding two or three degrees. Two new varieties of lettuce, $5 a$ and $5 b$, are being tested commercially; they mature ten to fourteen days earlier than Cheshunt Early Giant. One important experi. ment with tomatoes involved the lowering of $p H$ of the soil by the addition of sulphur and sulphuric acid. Sulphur, at the rate of $4 \mathrm{oz}$. per square yard, gave only a slightly increased yield of fruit, but the soil, originally $p \mathrm{H} 8 \cdot 79$, was still $p H \quad 7.45$ at the end of the season. Sulphuric acid caused the soil $p \mathrm{H}$ to fall from $8 \cdot 62$ to $6 \cdot 39$ in a week ; but within a month it had risen again to $7 \cdot 84$. It would seem that some upward movement of soil bases takes place. It is fairly easy to make soil more alkaline, but it is not so easy to render it more acid, and the results of any further work on these lines will be awaited with interest.

An earlier annual report described resistance of the tomato varieties Riverside and Manx Marvel to attack by the fungus Verticillium albo-atrum. This does not now seem to hold under all cultural conditions, according to $\mathrm{P}$. $\mathrm{H}$. Williams. I. W. Selman has had a similar action of soil conditions in mind in his attempts to provide cultural factors which would enable tomato plants infected with spotted wilt virus to carry a reasonable crop. This should be a very practical approach to minimizing the damage caused by this disease, provided that it is linked with adequate hygiene at the end of the season. Dr. Selman's work on this question is not very conclusive as yet, but his correlations of mosaic infection and soil conditions with blotchy ripening have given much more definite results. Unequal ripening seems to depend largely upon the waterretaining properties of a particular soil mixture. Steaming and the addition of peat without appropriate manurial adjustments, or the use of composts with extreme fluctuations in water content, both favour the trouble, which is, moreover, always increased by mosaic infection. Mrs. Enid Sheard has investigated the pathology of tomato stem rot caused by the fungus Didymella lycopersici. The pathogen is more virulent if it has wintered out of doors than at temperatures of about $59^{\circ} \mathrm{F}$. Tomato seed does not seem to carry the fungus, and the only really susceptible alternative host so far discovered is the egg plant, Solanum melongena. Many organic sub. stances allow saprophytic growth of the fungus, which seems to grow best at a temperature of $20^{\circ} \mathrm{C}$. W. H. Read has tried many substances and treatments for control, without much success, though

- Twenty-ninth Annual Report of the Nursery and Market Garden Industries' Development Society, Ltd., Turner's Hill, Cheshunt, Herts,
1944. 
No. 3951 July 21, 1945

mixtures containing salicylanilide give promise of protection upon the stems.

E. R. Speyer, studying the red-spider mite, finds that the application of top-dressings does not check infestation, and the use of petroleum emulsions provides the most practical control. The growth of wheat seedlings to act as bait for wireworm reduced their attack upon lettuce. $O$. Owen has investigated the interrelations of various nutrient elements for the tomato crop. Magnesium deficiency, for example, is related to nitrogen, and iron to manganese, while manganese and magnesium are possibly interdependent.

\section{STRUCTURE OF BIOLOGICAL FIBRES AND THE PROBLEM OF MUSCLE*}

TT is the mark of present-day biology that it looks ever more closely to "the Nature and Property of Local Motion" of the actual molecules of structures, and it is from such a point of view that the problem of muscle is again approached.

The physico-chemical mechanism of life is for the most part a manifestation of the forms and activities of chain-molecules, chief among which are the proteins, which include myosin, now generally accepted as the responsible contractile element of the muscle machine. X-ray studies show that myosin is a member of a family of fibrous proteins to which belong also the keratins of hair, etc., the fibrous proteins of the epidermis, and even fibrinogen and fibrin : all these are characterized by a similar molecular plan and by similar long-range elastic properties that rest on changes of form of the molecules themselves. The inference is that muscular activity is a special case of more general phenomena the full interpretation of which implies an understanding of the properties and significance of the keratin-myosin-fibrinogen group as a whole.

The isolated proteins of this group-and this holds too for the myosin in living muscle - oxist normally in a state in which the polypeptide chains are in a regularly folded configuration, but they may be pulled out into an extended configuration that is twice as long, and they may also be 'supercontracted' into more highly folded states. X-ray diffraction patterns of muscle, both living and dead, are throughout analogous to patterns that may be obtained from mammalian hairs, the 'supercontracted' state of the latter corresponding to the contracted state of the former. The outstanding common conclusion to be drawn from these photographs is that shortening is not a question of simple disorientation of fibrils, but rather of folding within fibrils.

Thermodynamic tests show that entropy changes play only a minor part in the elastic properties of keratin and isolated myosin, from which it is reasonable to suppose, especially in the light of the X-ray findings, that the various states of muscle itself are also based fundamentally on the potential energy associated with states of folding of the myosin chains. It now appears from recent physiological evidence that such a concept does indeed promise to coordinate quantitatively the energetics of living muscle.

* Substance of the Croonian Lecture delivered before the Royal Society by Dr. W. T. Astbury, F.R.S., on July 12.
A detailed solution of the muscle problem will be reached only as part of the detailed elucidation of protein structure, studied against the background of other macro-molecules, such as the nucleic acids and polysaccharides, with which protein activity is so intimately bound up. X-ray analysis is now boing supplemented by investigations with the electron microscope, and some of the evidence so obtained was presented.

\section{METER AND INSTRUMENT JEWELS AND PIVOTS}

TN order to obtain a more fundamental knowledge of the phenomena relating to meter and instrument bearings and to improve such bearings, research has been carried out for a number of years on behalf of the British Electrical and Allied Research Industries Association at the Meter Testing Laboratories of the Northmet Power Company. A paper read by G. F. Shotter before the Institution of Electrical Engineers in London on May 4 gives a brief survey of the various aspects covered by this research, dealing mainly with the sapphire/steel combination but including other combinations of materials.

The apparatus and methods of test are outlined, followed by a survey of the results from life-tests, including an analysis of the various factors which contribute to wear. The results of a microscopical examination of the units at the end of their life-run are discussed. A brief theory of the boundary lubrication existing in such bearings is given, with a short extract of the detailed discussion of the various factors contained in E.R.A. Reports.

The results of experiments on the resistance of sapphire jewels to impact forces are given; and the phenomena associated with bottom bearings at various loads, caused by parasitic forces existing in meters, are also dealt with. The actions of the balltype bearing and that of the pivot bearing are compared, and an approximate estimation of the life of bearings in practice, based on life-tests, is made.

A brief summary of the general conclusions reached during the tests is as follows. (a) Metals so far tried as alternatives to steel for pivots are in no way superior. The best material tested was osmiumrhodium, which gave good results in the dry as well as the lubricated condition. (b) With the exception of osmium-rhodium and possibly natural zircon $\left(90^{\circ}\right)$, the substitute materials tested, particularly glass, proved useless in the dry condition. (c) Various forms of oxide were produced, each having its own characteristics; one or two appeared to be selflubricating. (d) The initial friction of substitute materials was generally higher than that of the steel/ sapphire units. (e) With the exception of diamond, the substitute materials tested generally show a higher coefficient of friction than the steel/sapphire units. ( $f$ ) The range of penultimate/ultimate test values of friction shows considerable variation. Some materials, for example, natural zircon $\left(90^{\circ}\right)$, show a lower value than that of steel/sapphire. Other units, notably glass, give extremely high values, particularly in the dry condition. $(g)$ The type of wear area formed depends on the structure of the materials under test. Homogeneous and amorphous materials normally give circular wear. 